\title{
Label-Free Colorimetric Detection of Mercury (II) Ions Based on Gold Nanocatalysis
}

\author{
Pei-Chia Yang ${ }^{1}$, Tsunghsueh $\mathrm{Wu}^{2, *}$ and Yang-Wei Lin ${ }^{1, * \text { (D) }}$ \\ 1 Department of Chemistry, National Changhua University of Education, 1, Jin-De Road, \\ Changhua City 50007, Taiwan; po840603@yahoo.com.tw \\ 2 Department of Chemistry, University of Wisconsin-Platteville, 1 University Plaza, Platteville, \\ WI 53818-3099, USA \\ * Correspondence: wut@uwplatt.edu (T.W.); linywjerry@cc.ncue.edu.tw (Y.-W.L.); Tel.: +608-342-6018 (T.W.); \\ +886-723-2105-3553 (Y.-W.L.)
}

Received: 21 July 2018; Accepted: 22 August 2018; Published: 25 August 2018

check for updates

\begin{abstract}
Herein, a label-free colorimetric nanosensor for $\mathrm{Hg}(\mathrm{II})$ is developed utilizing the hindering effect of $\mathrm{Hg}$ (II) on the kinetic aspect of gold nanoparticle (AuNPs) growth on the surface of gold nanostars (AuNSs). H-AuNS probes are synthesized and modified by 2-[4-(2-hydroxyethel) piperazine-1-yl] ethanesulfonic acid (HEPES). After the formulation of the reagents and testing conditions are optimized, HEPES-capped AuNSs (H-AuNSs) demonstrates good selectivity and sensitivity towards $\mathrm{Hg}$ (II) determination. A H-AuNS probe, in the presence of $\mathrm{HCl} / \mathrm{Au}(\mathrm{III}) / \mathrm{H}_{2} \mathrm{O}_{2}$, is capable of detecting a $\mathrm{Hg}$ (II) concentration range of $1.0 \mathrm{nM}-100 \mu \mathrm{M}$, with a detection limit of $0.7 \mathrm{nM}$, at a signal-to-noise ratio of 3.0, and a visual detection limit of $10 \mathrm{nM}$ with naked eyes. For practicality, the $\mathrm{H}$-AuNS probe is evaluated by measuring $\mathrm{Hg}$ (II) in the environmental water matrices (lake water and seawater) by a standard addition and recovery study. The detection limits for environmental samples are found to be higher than the lab samples, but they are still within the maximum allowable $\mathrm{Hg}$ concentration in drinking water $(10 \mathrm{nM})$ set by the US Environmental Protection Agency (EPA). To create a unique nanosensor, the competitive interaction between $\mathrm{Hg}(\mathrm{II})$ and $\mathrm{Pt}(\mathrm{IV})$ toward the $\mathrm{H}$-AuNSs probe is developed into a logic gate, improving the specificity in the detection of $\mathrm{Hg}$ (II) ions in water samples.
\end{abstract}

Keywords: colorimetric detection; mercury; HEPES-gold nanostar; catalytic reduction

\section{Introduction}

The environmental conservation of fresh water resources and the efforts to protect fresh water from hazardous contaminants have become a primary priority in many countries. Mercury (Hg), existing in nature and being constantly produced by industries, had posed serious risks to the environment and has already caused harm to humans from its toxicity [1-4]. Early detection and intervention of the suspected pollution are critical to prevent a potential environmental tragedy such as the Minamata Disaster in Japan in 1956. Early detection can succeed if a simple and sensitive measuring tool is developed to quantify $\mathrm{Hg}$ (II) in fresh water resources. At present, several methods have been used for $\mathrm{Hg}$ (II) determination, such as atomic absorption spectrometry (AAS), atomic fluorescence spectrometry (AFS), stripping voltammetry, and polarography [5-7]. These analytical methods offer advantages in terms of good stability, selectivity, sensitivity, and legal acceptability as the national standard detection methods for many countries. The drawbacks of these methods include bulky instrumentation, high cost per analysis, long analysis time, stringent requirements of sample storage, highly trained personnel, and relatively expensive instruments, which thereby limits their use for fast $\mathrm{Hg}$ (II) monitoring in the field. Hence, a portable, facile, rapid, and low cost colorimetric method for $\mathrm{Hg}$ (II) detection is needed. 
Gold nanoparticles (AuNPs) have been exploited for chemical sensors and biosensors because of their unique physical and optical properties such as surface plasmon resonance (SPR), surface enhanced Raman scattering (SERS), and catalytic properties [8,9]. Currently, numerous detection methods of $\mathrm{Hg}$ (II) based on AuNPs have been reported, such as the aptamer and the functionalized AuNP nanosensor [10-14]. Much previous work utilized the aggregation of functionalized AuNPs from their chemical interaction with $\mathrm{Hg}$ (II) to produce a change in optical properties of AuNPs, with limit detections of 10 to $250 \mathrm{nM}$ [8,9]. However, the success of $\mathrm{Hg}$ (II) induced aggregation is highly dependent on the recognized ligand, which greatly influences the size of nanoparticles [15]. The induced aggregate can also be influenced by the ionic strength of the sample matrix. Our previous study has demonstrated a sensitive and selective method for $\mathrm{Hg}$ (II) detection based on the silver nanoparticle catalytic assisted growth of AuNPs in the presence of $\mathrm{Au}(\mathrm{III}) / \mathrm{HCl} / \mathrm{H}_{2} \mathrm{O}_{2}$ [16]. But the detection principle relies greatly on surface enhanced Raman scattering, which requires complex instrumentation and a tedious operation procedure as the main challenges for Raman based detection.

In this study, 2-[4-(2-hydroxyethel) piperazine-1-yl] ethanesulfonic acid (HEPES)-capped gold nanostars (H-AuNSs) were synthesized, and they showed a promising catalytic reduction of $\mathrm{Au}(\mathrm{III})$, which can be inhibited by the presence of $\mathrm{Hg}$ (II). The ultraviolet-visible spectroscopy (UV-Vis), transmission electron microscopy (TEM), and energy-dispersive X-ray spectroscopy (EDX) spectra were employed to elucidate its sensing mechanism. The goal of this study is to demonstrate a label-free, rapid, low-cost, highly selective and sensitive colorimetric method for detection of $\mathrm{Hg}$ (II) in natural water matrices. Although the use of HEPES for the synthesis of AuNPs has been reported during the course of the present investigation [17-23], the properties of catalytic reduction of $\mathrm{Au}(\mathrm{III})$ in the presence of $\mathrm{Hg}$ (II) have not been investigated. Compared to the commonly used chemicals (such as cetyltrimethylammonium bromide, sodium dodecyl sulfate, bis (p-sulfonatophenyl) phenylphosphine dipotassium salt, and poly(vinylpyrrolidone)) for the synthesis of AuNSs [24-30], HEPES is considered an environmentally-friendly green reagent and is used extensively in chemistry and biochemistry laboratories. This is because it possesses several properties, including maximum aqueous solubility, minimal salt and temperature effects, and high chemical stability. Finally, a NIMPLY gate is the negation of material implication [31]. This means that the material nonimplication from $P$ to $Q$ is true only if $\mathrm{P}$ is true and $\mathrm{Q}$ is false. Therefore, the competitive interactions between the $\mathrm{Hg}(\mathrm{II})$ and $\mathrm{Pt}(\mathrm{IV})$ toward the H-AuNSs allowed us to develop a NIMPLY logic gate to improve the specificity of this nanosensor.

\section{Materials and Methods}

\subsection{Chemicals}

All chemicals were purchased from Sigma-Aldrich (Milwaukee, WI, USA). All the reagents including $\mathrm{HAuCl}_{4}, \mathrm{H}_{2} \mathrm{O}_{2}, \mathrm{HCl}, \mathrm{NaOH}, \mathrm{HEPES}, \mathrm{HgCl}_{2}, \mathrm{CoCl}_{2}, \mathrm{Cu}\left(\mathrm{NO}_{3}\right)_{2} \cdot 2.5 \mathrm{H}_{2} \mathrm{O}, \mathrm{Ni}\left(\mathrm{NO}_{3}\right)_{2} \cdot 6 \mathrm{H}_{2} \mathrm{O}$, $\mathrm{H}_{2} \mathrm{PtCl}_{6}, \mathrm{ZnCl}_{2}, \mathrm{NaNO}_{3}, \mathrm{KNO}_{3}, \mathrm{Ba}\left(\mathrm{NO}_{3}\right)_{2}, \mathrm{Mg}\left(\mathrm{NO}_{3}\right)_{2} \cdot 6 \mathrm{H}_{2} \mathrm{O}, \mathrm{CaCl}_{2} \cdot 2 \mathrm{H}_{2} \mathrm{O}, \mathrm{Sr}\left(\mathrm{NO}_{3}\right)_{2}, \mathrm{FeCl}_{2}, \mathrm{FeCl}_{3}$, $\mathrm{Cd}\left(\mathrm{NO}_{3}\right)_{2} \cdot 4 \mathrm{H}_{2} \mathrm{O}$, and $\mathrm{Pb}\left(\mathrm{NO}_{3}\right)_{2}$ were commercially available and of analytical reagent grade. Ultrapure water (18.2 M $\Omega$-cm resistivity) was used from a Milli-Q ultrapure system (Millipore, MA, USA).

\subsection{Preparation of $\mathrm{H}-\mathrm{AuNSS}$}

$\mathrm{H}$-AuNSs were synthesized by reducing $\mathrm{Au}(\mathrm{III})$ chloride in HEPES buffer at room temperature [18]. The H-AuNSs were prepared by mixing $100 \mu \mathrm{L}$ of $0.4 \mathrm{mM} \mathrm{HAuCl}_{4}$ with $100 \mu \mathrm{L}$ of $200 \mathrm{mM}$ HEPES buffer. The mixed solution was shaken for $1 \mathrm{~min}$ and then left to grow in the dark for $24 \mathrm{~h}$. For simplicity, the concentration of the as-prepared H-AuNS solution is defined as $1 \times$.

\subsection{Characterization}

A JEOL 2010 TEM (JEOL, Tokyo, Japan) with the acceleration voltage of $200 \mathrm{kV}$ was used to study the morphologies of the prepared H-AuNSs and AuNPs. EDX spectroscopy (Bruker Nano, Berlin, 
Germany) was used to reveal their elemental composition. An Evolution 200 UV-Vis spectrometer (ThermoFisher Scientific, Waltham, MA, USA) was used to record the UV-Vis spectra of the prepared H-AuNS and AuNP solutions. A dynamic light scattering (DLS) spectrophotometer (SZ-100, Horiba, Kyoto, Japan) was used to measure the hydrodynamic radius of the prepared H-AuNSs and AuNPs.

\subsection{General Procedure for Sensing $\mathrm{Hg}^{2+}$ Ions}

Stock solutions of the metal ions $(0.1 \mathrm{M})$ were prepared in $0.1 \mathrm{M} \mathrm{HNO}_{3}$. For the selectivity study $(n=3), 100 \mu \mathrm{L}$ aliquots of $150 \mu \mathrm{M}$ metal ion solution and $15 \mu \mathrm{M} \mathrm{Hg}$ (II) were prepared and then separately mixed with $200 \mu \mathrm{L}$ H-AuNS seed solution $(1 \times)$ for $3 \mathrm{~min}$. Next, the mixtures were added to 1.2-mL ultrapure water containing $150 \mu \mathrm{L} \mathrm{HCl}(10 \mathrm{mM}), 100 \mu \mathrm{L} \mathrm{HAuCl}_{4}(0.1 \%)$, and $50 \mu \mathrm{L} \mathrm{H}_{2} \mathrm{O}_{2}(0.3 \%)$. The mixtures were equilibrated at $60{ }^{\circ} \mathrm{C}$ for $10 \mathrm{~min}$. Finally, the UV-Vis spectra were measured using an Evolution $200 \mathrm{UV}$-Vis spectrometer. The formation of AuNPs could be kept at $4{ }^{\circ} \mathrm{C}$ and exhibited no precipitation for 3 days.

\subsection{General Procedure for NIMPLY Logic Gate}

For the NIMPLY logic gate study ( $n=3), 100 \mu \mathrm{L}$ aliquots of $150 \mu \mathrm{M} \mathrm{Pt}(\mathrm{IV})$ and $150 \mu \mathrm{M} \mathrm{Hg}$ (II) were simultaneously mixed with $200 \mu \mathrm{L} \mathrm{H}$-AuNS seed solution $(1 \times)$ for $3 \mathrm{~min}$. Next, the mixtures were added to $1.1-\mathrm{mL}$ ultrapure water containing $150 \mu \mathrm{L} \mathrm{HCl}(10 \mathrm{mM}), 100 \mu \mathrm{L} \mathrm{HAuCl}{ }_{4}(0.1 \%)$, and $50 \mu \mathrm{L} \mathrm{H}_{2} \mathrm{O}_{2}(0.3 \%)$. The mixtures were equilibrated at $60^{\circ} \mathrm{C}$ for $10 \mathrm{~min}$. Finally, the UV-Vis spectra were measured using an Evolution $200 \mathrm{UV}$-Vis spectrometer.

\section{Results and Discussion}

\subsection{Sensing Mechanism}

The sensing mechanism for this study is illustrated in Scheme 1. H-AuNSs were prepared by the reduction of gold chloride in a HEPES buffer at room temperature [18]. Upon the addition of $\mathrm{Au}(\mathrm{III})$ to $\mathrm{H}$-AuNSs solution, $\mathrm{Au}(\mathrm{III})$ ions were adsorbed onto the $\mathrm{H}$-AuNS surface from electrostatic interactions between $\mathrm{Au}(\mathrm{III})$ and the negatively charged HEPES on the H-AuNS surface [32]. Subsequently, these $\mathrm{Au}(\mathrm{III})$ ions were reduced to $\mathrm{Au}(\mathrm{I})$ due to the reducing power of the HEPES layer. As a result, the standard electrode potential of $\mathrm{Au}(\mathrm{I})\left(\mathrm{E}^{0} \mathrm{Au}(\mathrm{I}) / \mathrm{Au}: 1.83 \mathrm{~V}\right)$ is larger than that of $\mathrm{H}_{2} \mathrm{O}_{2}\left(\mathrm{E}^{0}{ }_{\mathrm{H} 2 \mathrm{O}} / \mathrm{H} 2 \mathrm{O}\right.$ : $1.77 \mathrm{~V})$, favoring the reduction at the solid-liquid interface to form AuNPs in the presence of $\mathrm{HCl}$ [33]. When $\mathrm{Hg}$ (II) ions were pre-mixed with $\mathrm{H}$-AuNSs, the formation of a AuHg amalgam occurred [34,35] and reduced the $\mathrm{H}$-AuNSs surface area for adsorption of $\mathrm{Au}(\mathrm{III})$ on the gold surface. The un-reacted $\mathrm{H}-\mathrm{AuNSs}$ and the AuHg amalgam acted as seeds for the growth of AuNPs in the $\mathrm{HCl} / \mathrm{Au}(\mathrm{III}) / \mathrm{H}_{2} \mathrm{O}_{2}$ solution. As a result, the color of the H-AuNS solution gradually turned from light purple to red during this process. The color intensity of a treated water sample offers the visual determination of mercury, and it can directly relate to the amount of $\mathrm{Hg}$ (II) present in the water samples. Furthermore, the relative change of the SPR band in the resulting AuNPs, formed between the absence and presence of $\mathrm{Hg}(\mathrm{II})$ ions, can offer a more sensitive instrumental method to quantify $\mathrm{Hg}(\mathrm{II})$ in the water samples. 


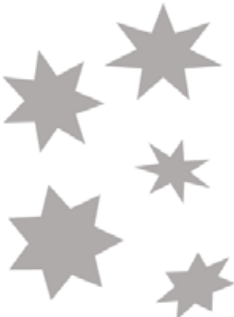

H-AuNSs

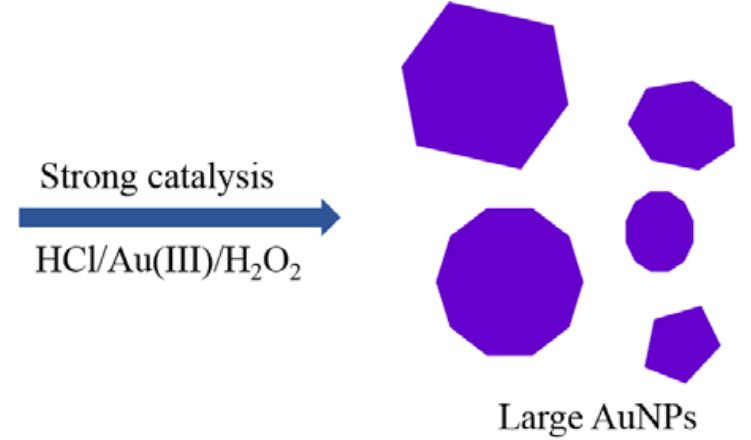

Weak catalysis

$\mathrm{HCl} / \mathrm{Au}(\mathrm{III}) / \mathrm{H}_{2} \mathrm{O}_{2}$

Small AuNPs

Scheme 1. Colorimetric detection of $\mathrm{Hg}$ (II) based on its inhibition of $\mathrm{H}$-AuNS catalytic reduction of $\mathrm{Au}(\mathrm{III})$ in the presence of $\mathrm{HCl}$ and $\mathrm{H}_{2} \mathrm{O}_{2}$.

Figure 1 shows the absorbance spectra of the $\mathrm{H}$-AuNS probes without and with $\mathrm{Hg}$ (II) in the presence of the $\mathrm{HCl} / \mathrm{Au}(\mathrm{III}) / \mathrm{H}_{2} \mathrm{O}_{2}$ solution. As can be seen in Figure 1 (black curve), the initial $\mathrm{H}$-AgNSs possessed a SPR peak at $700 \mathrm{~nm}$. This SPR band blue-shifted to $580 \mathrm{~nm}$ when $150 \mu \mathrm{L}$ $\mathrm{HCl}(10 \mathrm{mM}), 100 \mu \mathrm{L} \mathrm{Au}(\mathrm{III})(0.1 \%)$, and $50 \mu \mathrm{L} \mathrm{H}_{2} \mathrm{O}_{2}(0.3 \%)$ were added to the H-AuNS solution (red curve). After adding the $\mathrm{HCl} / \mathrm{Au}(\mathrm{III}) / \mathrm{H}_{2} \mathrm{O}_{2}$ solution to the $\mathrm{H}$-AuNS solution, a reduction reaction took place on the surface of $\mathrm{H}$-AuNSs, generating a different morphology of AuNPs and causing the blue shift in the SPR band. After adding $100-\mu \mathrm{M} \mathrm{Hg}$ (II) to the H-AuNS solution and then following with the addition of $\mathrm{HCl} / \mathrm{Au}(\mathrm{III}) / \mathrm{H}_{2} \mathrm{O}_{2}$ solution, the SPR absorbance further blue-shifted to $530 \mathrm{~nm}$ (blue curve), indicating the formation of small-sized AuNPs. We suggested that the AuHg amalgam acted as nucleation seeds for the growth of small AuNPs. Thus, the blue-shifted wavelength of the SPR band was due to both the change of the particle morphologies and the dielectric constants. This also explains why the color of the AuNP solution gradually became red, providing the sensing principle for the determination of $\mathrm{Hg}$ (II) in the aqueous solution. Therefore, the $\mathrm{Hg}$ (II) concentration can be determined by monitoring relative changes in the SPR band ratio $\left(\left(R-R_{0}\right) / R_{0}\right)$ of the produced AuNPs, where $R$ and $R_{0}$ represent the SPR band ratio $\left(A_{580} / A_{530}\right)$ of the AuNPs in the presence and absence of $\mathrm{Hg}$ (II), respectively. The higher relative changes in the SPR band ratio indicated a higher extent of the AuHg amalgam formation, resulting in a larger increase in the number of small AuNPs. 


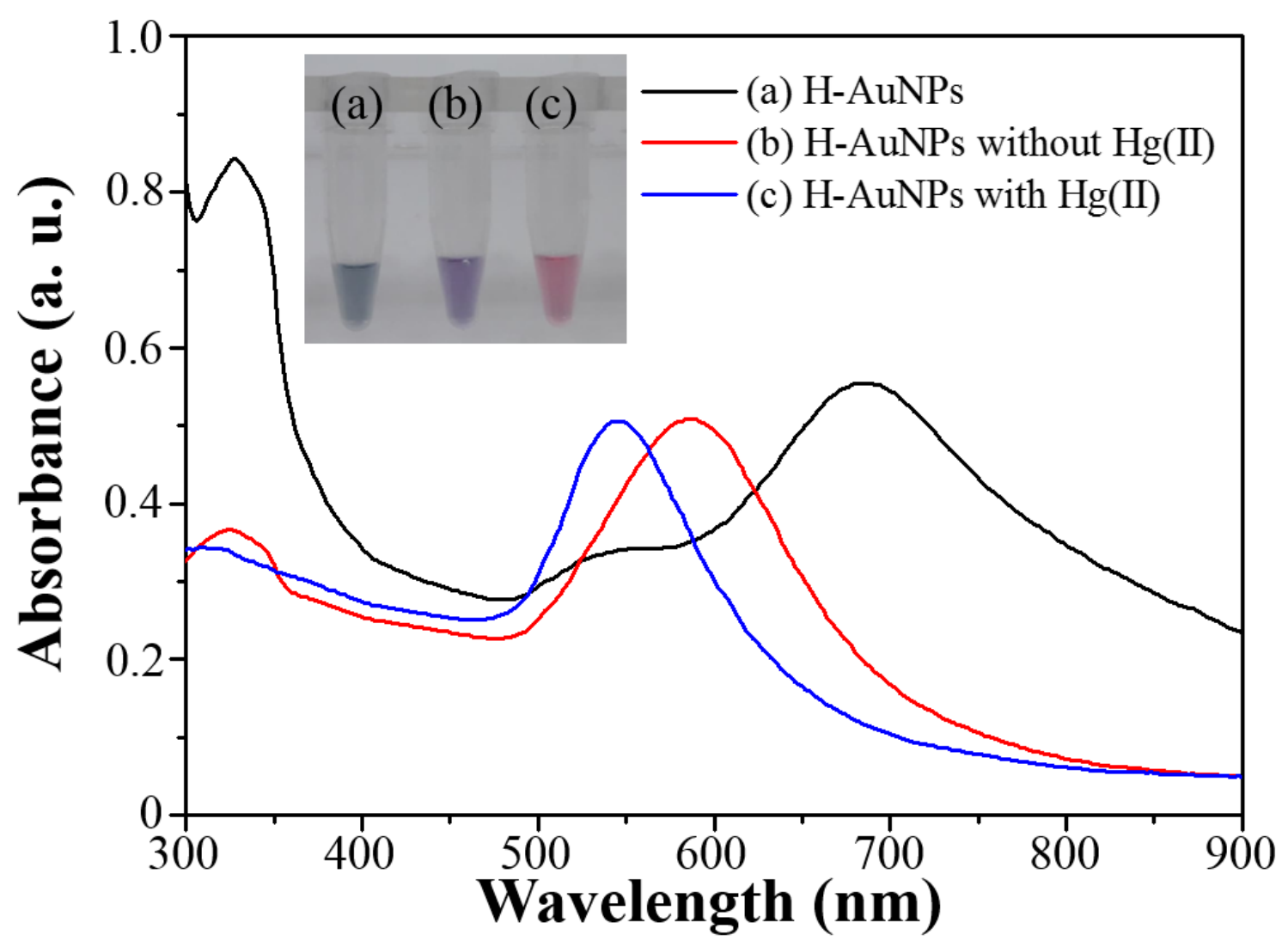

Figure 1. UV-Vis spectra of (a) the H-AuNS probe prior to the reactions and the H-AuNS probe, (b) without and (c) with $\mathrm{Hg}(\mathrm{II})(1.0 \mu \mathrm{M})$ in the presence of the $\mathrm{HCl} / \mathrm{Au}(\mathrm{III}) / \mathrm{H}_{2} \mathrm{O}_{2}$ solution. Inset: color visualization for (a), (b) and (c).

Figure 2 represents the TEM images and EDX spectrum of the corresponding Au nanomaterials. Prior to the reaction, the H-AgNSs typically had 4-8 branches, with an average tip-to-tip distance of $42.5 \pm 0.7 \mathrm{~nm}$ from TEM measurements (Figure 2a). In the absence of $\mathrm{Hg}$ (II), Au(III) adsorbed on the H-AuNS surface and reduced to form irregular AuNPs with a diameter of $88.8 \pm 6.5 \mathrm{~nm}$ (Figure $2 b$ ). However, when $\mathrm{Hg}$ (II) was present, the AuNPs produced were smaller than those without $\mathrm{Hg}$ (II) (Figure 2c), and they possessed more spherical morphology with an average diameter of $48.2 \pm 4.0 \mathrm{~nm}$. These observations reveal that $\mathrm{Hg}$ (II) caused the shape and size change of H-AuNSs in the $\mathrm{HCl} / \mathrm{Au}(\mathrm{III}) / \mathrm{H}_{2} \mathrm{O}_{2}$ system and enhanced the formation of a thermodynamically-favored resembling spherical surface. Meanwhile, EDX analysis provided more evidence that AuNSs and AuNPs for Figure 2a,b respectively contain no mercury element. The EDX spectrum of the produced AuNPs for Figure 2c indicates the co-existence of Au and Hg elements, supporting the formation of the AuHg amalgam (Figure 2d). 


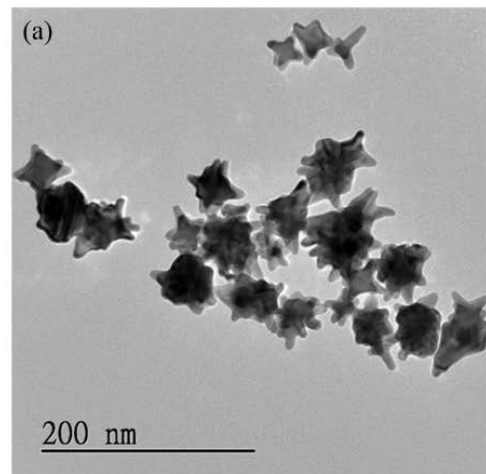

(b)

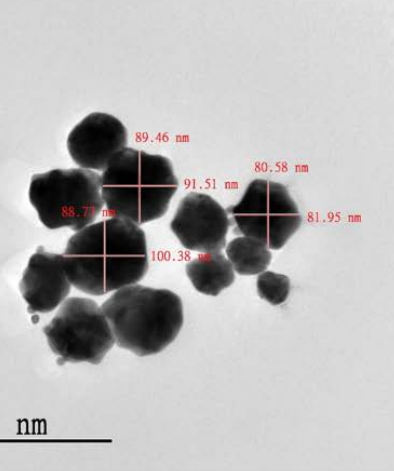

(c)

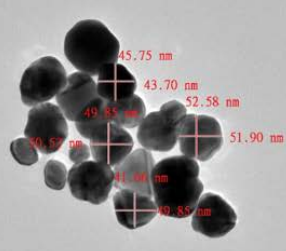

$200 \mathrm{~nm}$

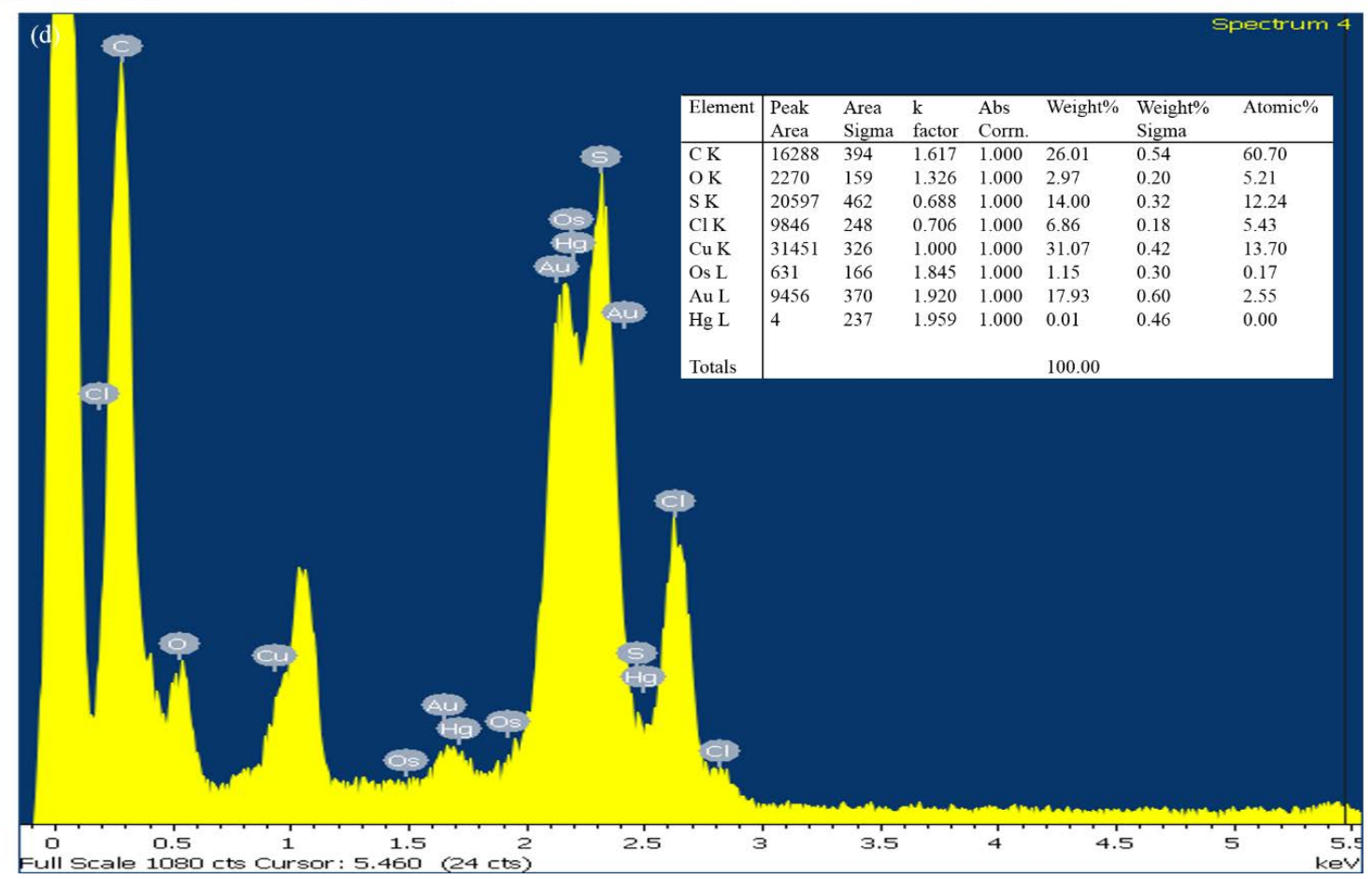

Figure 2. TEM images of (a) the H-AuNS probe prior to the reaction; and the H-AuNS probe (b) without and (c) with $\mathrm{Hg}(\mathrm{II})(1.0 \mu \mathrm{M})$ in the presence of $\mathrm{HCl} / \mathrm{Au}(\mathrm{III}) / \mathrm{H}_{2} \mathrm{O}_{2}$ solution. (d) EDX spectrum of the $\mathrm{H}-\mathrm{AuNS}$ probe with $\mathrm{Hg}(\mathrm{II})$ in the presence of $\mathrm{HCl} / \mathrm{Au}(\mathrm{III}) / \mathrm{H}_{2} \mathrm{O}_{2}$ solution.

Investigation on the effects of $\mathrm{Hg}(\mathrm{II})$ on the size and shape change in H-AsNSs was carried out with UV-Vis, TEM, and dynamic light scattering to gain a deeper understanding of the H-AuNS dissolution process. First, the $\mathrm{H}-\mathrm{AuNS}$ probe was mixed with $\mathrm{Hg}$ (II) alone, and the change in its optical property from UV-Vis was observed in Figure 3. Adding Hg(II) to the H-AuNSs solution decreased the SPR absorbance (red curve), which reflects the change of the particle morphologies and dielectric constants upon the reaction between AuNSs and $\mathrm{Hg}$ (II). Second, the morphology change from the reaction between AuNS and Hg(II) was observed by TEM, as shown in Figure 4. From the TEM image, noticeable branches were observed in AuNSs, and the number and the size of branches were reduced after reacting with $\mathrm{Hg}$ (II) for $10 \mathrm{~min}$. The size was reduced upon the addition of $\mathrm{Hg}$ (II); the widths of the H-AuNSs without and with $\mathrm{Hg}$ (II) were $42.5 \pm 0.7$ and $38.4 \pm 3.3 \mathrm{~nm}$, respectively. Third, EDX again confirmed the coexistence of Au and Hg elements, as shown in Figure 4b. Finally, dynamic light scattering determined that the effective hydrodynamic diameter of the AuNPs without and with $\mathrm{Hg}$ (II) were $67.5 \pm 8.8$ and $48.3 \pm 4.4 \mathrm{~nm}$, respectively (Figure 5). All results indicated that $\mathrm{Hg}$ (II) effectively dissolved H-AuNSs because of the AuHg amalgam formation. 


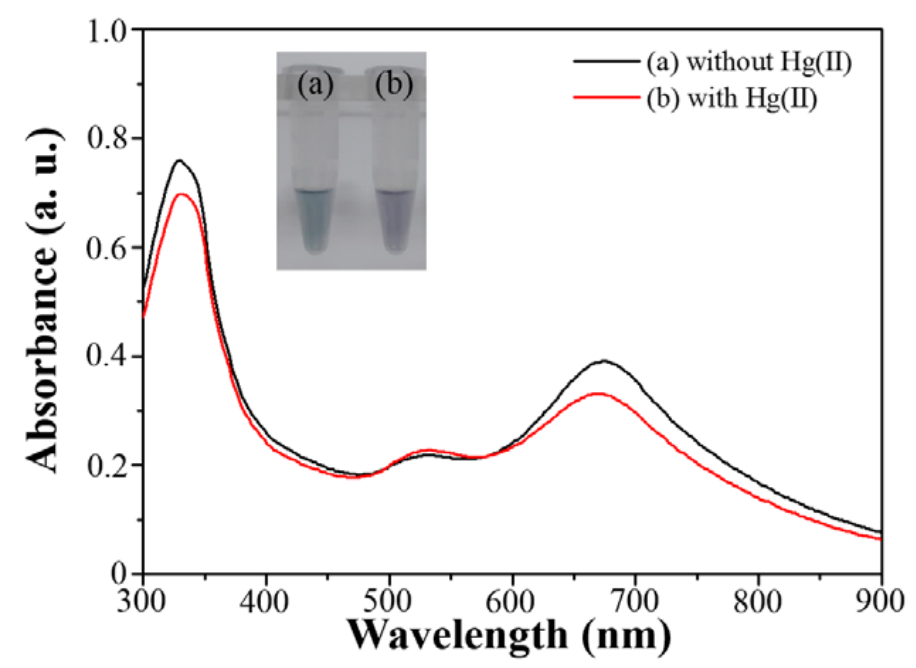

Figure 3. UV-Vis spectra of the H-AuNS probe (a) without and (b) with $\mathrm{Hg}(\mathrm{II})(1.0 \mu \mathrm{M})$ in the absence of $\mathrm{HCl} / \mathrm{Au}(\mathrm{III}) / \mathrm{H}_{2} \mathrm{O}_{2}$ solutions. Inset: photographs of the prepared AuNPs solutions.
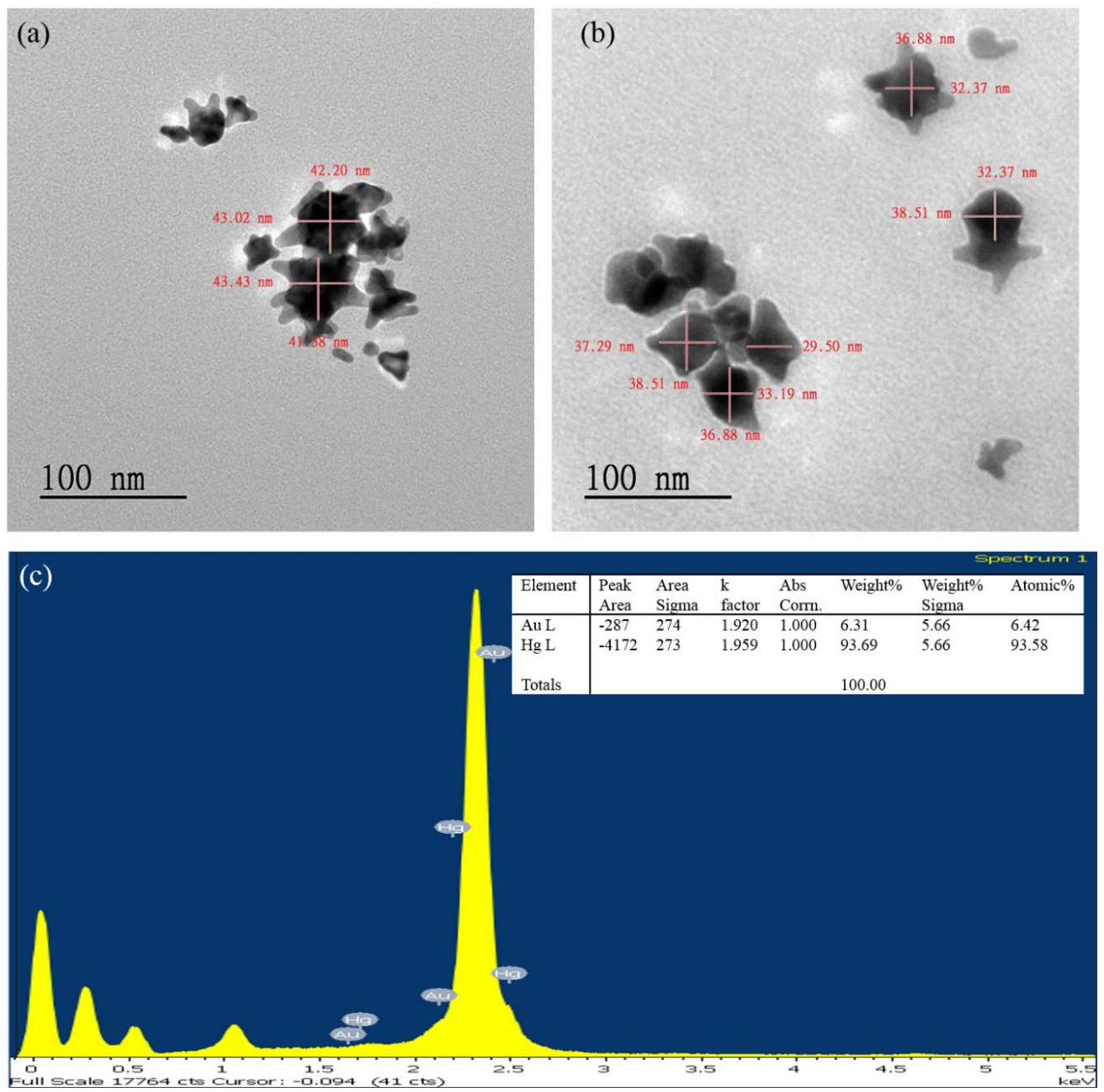

Figure 4. TEM images of the H-AuNS probe (a) without and (b) with $\mathrm{Hg}(\mathrm{II})(1.0 \mu \mathrm{M})$ in the absence of $\mathrm{HCl} / \mathrm{Au}(\mathrm{III}) / \mathrm{H}_{2} \mathrm{O}_{2}$ solutions; (c) EDX spectrum of the $\mathrm{H}$-AuNS probe with $\mathrm{Hg}(\mathrm{II})$ in the absence of $\mathrm{HCl} / \mathrm{Au}(\mathrm{III}) / \mathrm{H}_{2} \mathrm{O}_{2}$ solution. 


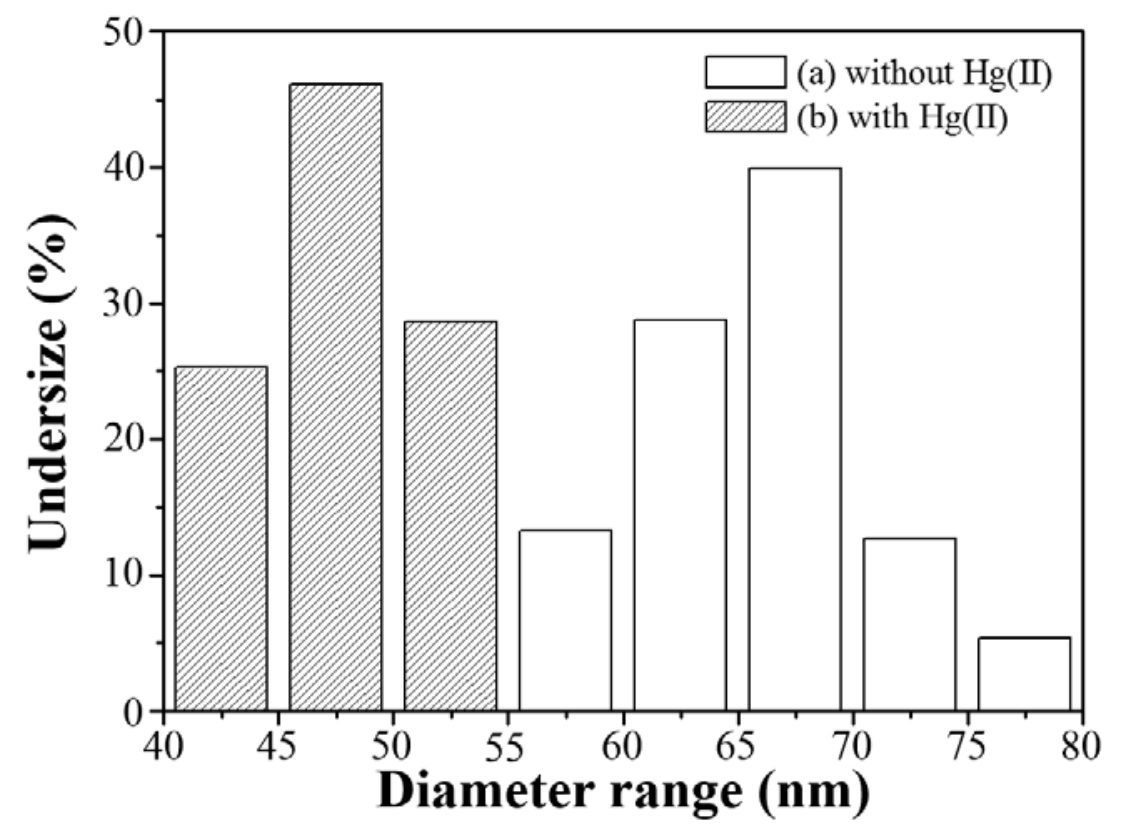

Figure 5. Hydrodynamic diameter distribution of the AuNPs solutions (a) without and (b) with $\mathrm{Hg}$ (II) $(1.0 \mu \mathrm{M})$ by dynamic light scattering technique.

\subsection{Sensing System Optimization}

Factors for the performance of the $\mathrm{H}$-AuNS probe in $\mathrm{Hg}$ (II) determination, such as solution volumes of reagents $\left(1 \times \mathrm{H}\right.$-AuNSs, $10 \mathrm{mMHCl}, 0.1 \% \mathrm{Au}(\mathrm{III})$, and $\left.0.3 \% \mathrm{H}_{2} \mathrm{O}_{2}\right)$, reaction temperature, and time, were evaluated based on the relative change in the SPR band ratio, $\left(R_{0}-R\right) / R_{0}$, of the AuNPs, where $R$ and $R_{0}$ represent that SPR band ratio $\left(A_{580} / A_{530}\right)$ of the AuNPs in the presence and absence of $\mathrm{Hg}(\mathrm{II})$ ions, respectively. The volume of reagents was studied first to generate an optimized formulation for the subsequent study and real sample analysis. The effect of $\mathrm{H}$-AuNS volumes on the determination of $\mathrm{Hg}$ (II) $(1.0 \mu \mathrm{M})$ was investigated in the range of $10 \mu \mathrm{L}$ to $250 \mu \mathrm{L}$, and Figure $6 \mathrm{a}$ shows that a volume of $200 \mu \mathrm{L}$ offers the highest SPR band ratio. A higher concentration of H-AuNSs provides a seeding surface to form AuNPs subsequently in the presence of $\mathrm{HCl} / \mathrm{Au}(\mathrm{III}) / \mathrm{H}_{2} \mathrm{O}_{2}$. In the presence of $\mathrm{Hg}(\mathrm{II})$, the formation of AuNPs was hindered by the reduced AuNS surface area and the possible change on surface composition, resulting in favorable formation of small AuNPs. Next, the role of $\mathrm{HCl}$ in this sensing platform is to catalyze the formation of AuNPs in the presence of the $\mathrm{Au}(\mathrm{III}) / \mathrm{H}_{2} \mathrm{O}_{2}$ solution. $150 \mu \mathrm{L} \mathrm{HCl}$ was determined as the optimum volume (Figure $6 \mathrm{~b}$ ). With the set $\mathrm{H}$-AuNS and $\mathrm{HCl}$ volume, the optimum volume of $\mathrm{Au}(\mathrm{III})$ for the further growth AuNPs was found to be $100 \mu \mathrm{L}$ (Figure 6c). Moreover, the dissolving effect gradually increased with an increasing volume of $\mathrm{H}_{2} \mathrm{O}_{2}$ before reaching a plateau at about $50 \mu \mathrm{L}$ of $\mathrm{H}_{2} \mathrm{O}_{2}$ added (Figure $6 \mathrm{~d}$ ). Thus, the optimum volume of $\mathrm{H}_{2} \mathrm{O}_{2}$ was $50 \mu \mathrm{L}$ for the following experiment. Interestingly, the optimization study has shown that the sensitivity of the H-AuNS probe increases with an increase in all four reagents, as they all favor the formation of small AuNPs in the presence of $\mathrm{Hg}(\mathrm{II})$, supporting the mechanism of sensing strategy. 

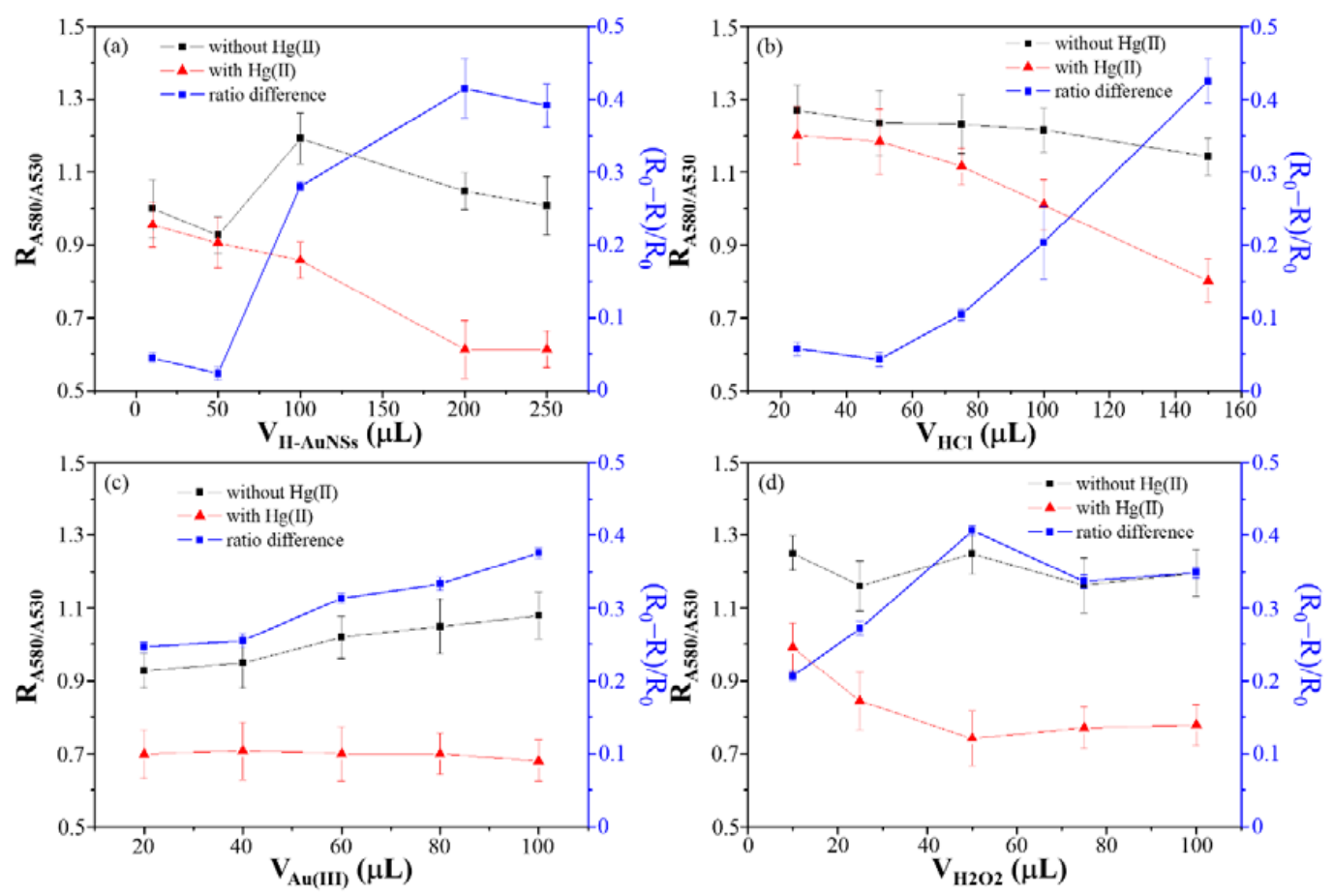

Figure 6. SPR band ratios (R: $\left.A_{580} / A_{530}\right)$ to evaluate the catalytic effects of the H-AuNS probe $(\square)$ on AuNP growth without $(\boldsymbol{\square})$ and with $(\boldsymbol{\Delta})$ of $\mathrm{Hg}(\mathrm{II})(1.0 \mu \mathrm{M})$ in the presence of $\mathrm{HCl} / \mathrm{Au}(\mathrm{III}) / \mathrm{H}_{2} \mathrm{O}_{2}$ solution, at different volumes of (a) $\mathrm{H}$-AuNSs, (b) $\mathrm{HCl}$, (c) $\mathrm{Au}(\mathrm{III})$, and (d) $\mathrm{H}_{2} \mathrm{O}_{2}$. Error bars represent standard deviations from three repeated experiments.

The effect of temperature on the change in SPR band ratio was investigated over the range 30-70 ${ }^{\circ} \mathrm{C}$. In Figure 7a, the SPR band change ratio in the sensing system increased with an increase in the reaction temperature before reaching a plateau at $60^{\circ} \mathrm{C}$ (Figure 7a). As the temperature increased, the frequency of collisions between $\mathrm{Hg}$ (II) and $\mathrm{H}$-AuNSs increased, resulting in an increased degree of dissolution for H-AuNSs. At a fixed temperature at $60{ }^{\circ} \mathrm{C}$, the change in SPR ratio only increased slightly as time elapsed, reaching a maximum at $30 \mathrm{~min}$, which was attributed to the dissolving rate for the H-AuNSs reaching the maximum (Figure 7b). Fortunately, a majority of AuNPs was formed and stabilized within the first $10 \mathrm{~min}$ of reaction. Therefore, a temperature of $60{ }^{\circ} \mathrm{C}$ and a reaction time of $10 \mathrm{~min}$ were chosen for water analysis.
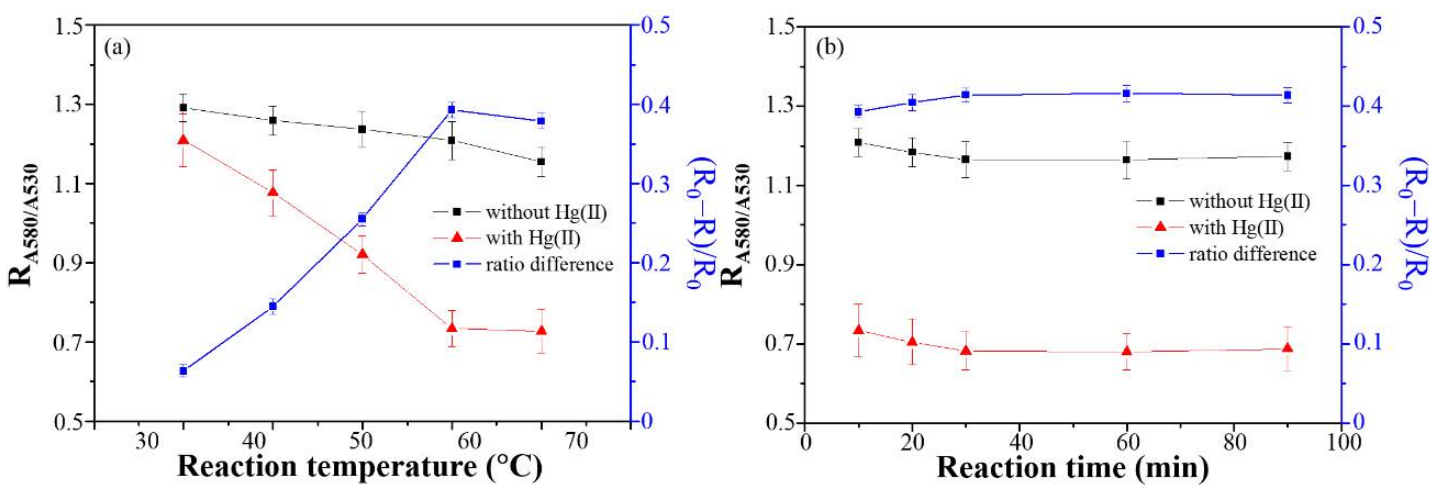

Figure 7. Absorbance ratios (R: $\left.A_{580} / A_{530}\right)$ and catalytic effects ( $\left.\square\right)$ for the $\mathrm{H}$-AuNS probe without and with $(\boldsymbol{\Delta})$ of $\mathrm{Hg}(\mathrm{II})(1.0 \mu \mathrm{M})$ in the presence of $\mathrm{HCl} / \mathrm{Au}(\mathrm{III}) / \mathrm{H}_{2} \mathrm{O}_{2}$ solution, at different (a) reaction temperatures and (b) times. Error bars represent standard deviations from three repeated experiments. 


\subsection{Selectivity and Sensitivity of the Sensing System}

With the optimized conditions, the selectivity of the H-AuNS probe was evaluated in the presence of other metal ions at a concentration of $10.0 \mu \mathrm{M}$. As shown in Figure 8, the change in the SPR ratio by non-mercuric metal ions was at most insignificant compared with the system with $1.0 \mu \mathrm{M} \mathrm{Hg}$ (II) alone. On the basis of analysis of variance $\left(95 \%\right.$ confidence level, $\left.\mathrm{F}_{\text {critical }}=1.66\right)$ and the least significant difference method, the $\left(R_{0}-R\right) / R_{0}$ value obtained using the $\mathrm{H}$-AuNs probe in the presence of $\mathrm{Hg}$ (II) is a significant difference among those in the presence of non-mercuric metal ions. This is because $\mathrm{Hg}$ (II) effectively dissolved $\mathrm{H}$-AuNSs due to the $\mathrm{AuHg}$ amalgam formation, resulting in the growth of small AuNPs. Among all the ions tested, iron (II), sodium, calcium, lead, and cadmium also showed some degree of change. This suggests these ions, at a higher concentration, can pose some challenges in water analysis, but standard addition, shown in a later section of this report, was developed to reduce their interferences.

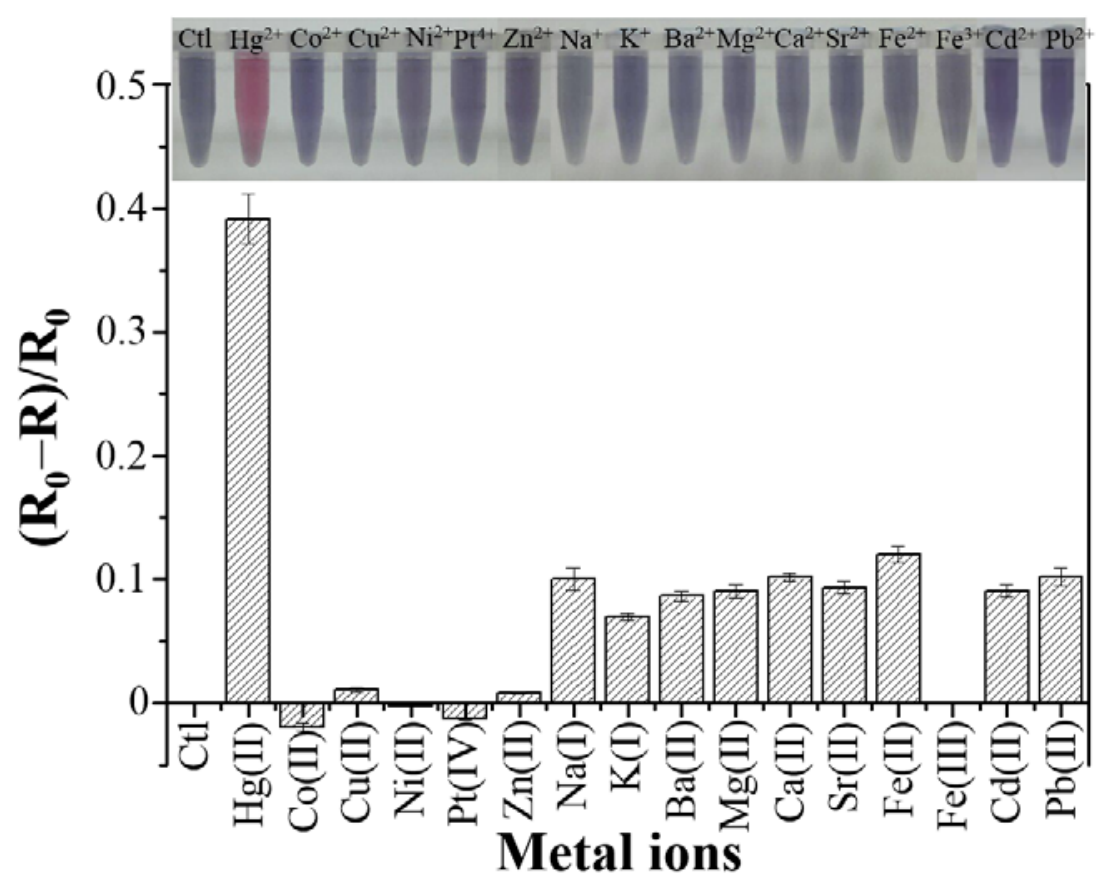

Figure 8. Selectivity of the $\mathrm{H}$-AuNS probe in the presence of $\mathrm{HCl} / \mathrm{Au}(\mathrm{III}) / \mathrm{H}_{2} \mathrm{O}_{2}$ solution toward $\mathrm{Hg}$ (II) ions. The $\mathrm{Hg}$ (II) concentration was $1.0 \mu \mathrm{M}$, and the concentration of each of the other metal ions was $10 \mu \mathrm{M}$. Inset: photographs of the H-AuNS probe with different metal ions in the presence of $\mathrm{HCl} / \mathrm{Au}(\mathrm{III}) / \mathrm{H}_{2} \mathrm{O}_{2}$ solution. Error bars represent standard deviations from three repeated experiments.

The sensitivity of the $\mathrm{H}$-AuNS probe in the presence of the $\mathrm{HCl} / \mathrm{Au}(\mathrm{III}) / \mathrm{H}_{2} \mathrm{O}_{2}$ solution was studied at its optimum conditions after being equilibrated at $60^{\circ} \mathrm{C}$ for $10 \mathrm{~min}$ by lowering the $\mathrm{Hg}$ (II) concentration to a level where the color change of the AuNP solution was detectable with the naked eye. At the same time, the UV-Vis spectra of the AuNP solutions containing different $\mathrm{Hg}$ (II) concentrations were examined for the construction of a quantitative assay. A blue shift from the SPR perspective, or a red shift from the visual inspection, was distinctively observable with an increase in the $\mathrm{Hg}$ (II) concentration, as shown in Figure 9a. The color of the solutions changed from light purple to red as the $\mathrm{Hg}$ (II) concentration was increased from $1.0 \mathrm{nM}$ to $100 \mu \mathrm{M}$ (Inset image in Figure $9 \mathrm{~b}$ ). The visual detection limit for $\mathrm{Hg}(\mathrm{II})$ was $10.0 \mathrm{nM}$ with the naked eye. A linear relationship was found between the ratio $\left(R_{0}-R\right) / R_{0}$ and the logarithmic concentration of $\mathrm{Hg}$ (II) over the range $1.0 \mathrm{nM}-100 \mu \mathrm{M}$, and the linear correlation coefficient was 0.9607 . Considering a signal-to-noise ratio of 3 , the limit of detection (LOD) for $\mathrm{Hg}(\mathrm{II})$ by the $\mathrm{H}-\mathrm{AuNS}$ probe was $0.7 \mathrm{nM}$. This result suggested that the $\mathrm{H}-\mathrm{AuNS}$ probe, in the presence of the $\mathrm{HCl} / \mathrm{Au}(\mathrm{III}) / \mathrm{H}_{2} \mathrm{O}_{2}$ solution, is well-suited for monitoring $\mathrm{Hg}$ (II) ions 
in environmental water samples, as the probe can detect $\mathrm{Hg}(\mathrm{II})$ lower than US EPA drinking water standard for the highest $\mathrm{Hg}$ (II) concentration permitted in drinking water at $10.0 \mathrm{nM}$.
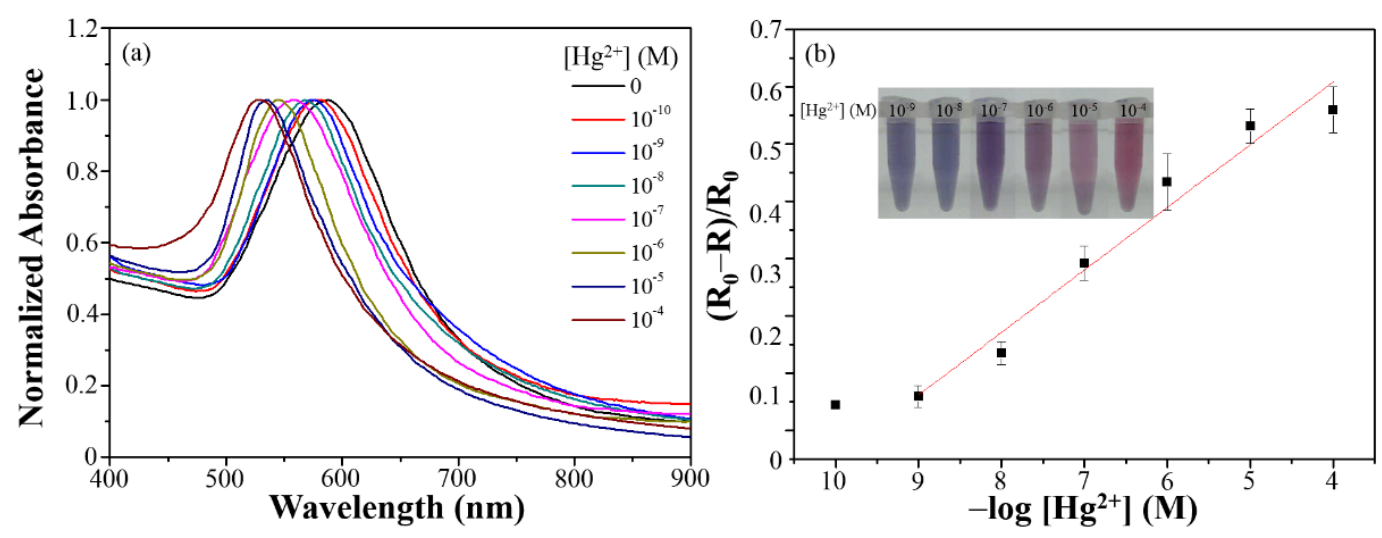

Figure 9. (a) UV-Vis absorbance spectra and (b) linear responses of the catalytic effect plotted against the $\mathrm{Hg}$ (II) concentration. Inset: photographs of the $\mathrm{H}$-AuNS probe in the presence of $\mathrm{HCl} / \mathrm{Au}(\mathrm{III}) / \mathrm{H}_{2} \mathrm{O}_{2}$ solution at different $\mathrm{Hg}$ (II) concentrations. Error bars represent standard deviations from three repeated experiments.

\subsection{Application of the Sensing System}

For practicality, the prepared $\mathrm{H}-\mathrm{AuNS}$ probe in the presence of the $\mathrm{HCl} / \mathrm{Au}(\mathrm{III}) / \mathrm{H}_{2} \mathrm{O}_{2}$ solution was used for detecting $\mathrm{Hg}$ (II) in environmental water matrices. A fresh water sample from Sun Moon Lake in Nantou and a seawater sample from the beach in Taichung were each filtered through a $0.2 \mu \mathrm{m}$ membrane. The filtered samples were analyzed by ICP-MS. Both water samples contained $\mathrm{Hg}$ (II) concentrations below the LOD of our probe when $0.9 \mathrm{~mL}$ of the sample was added to $0.6 \mathrm{~mL}$ of $\mathrm{HCl} / \mathrm{Au}(\mathrm{III}) / \mathrm{H}_{2} \mathrm{O}_{2}$ solution containing $\mathrm{H}$-AuNS probes. Standard addition is a well-accepted quantitative analysis technique to analyze $\mathrm{Hg}$ (II) ions in complicated matrices. In this standard addition study, a linear correlation between the $\left(R_{0}-R\right) / R_{0}$ value and the spiked $\mathrm{Hg}$ (II) concentration was found over the $\mathrm{Hg}$ (II) concentration range of $10.0 \mathrm{nM}-100.0 \mu \mathrm{M}$, and the recoveries for the lake water and seawater samples were determined to be $92.1-117.1 \%$ and $88.9-119.1 \%$, respectively. The LODs for $\mathrm{Hg}$ (II) in the lake water and seawater samples were 6.3 and $8.9 \mathrm{nM}$, respectively, which are low enough for the H-AuNS probe to be promising in environmental monitoring.

Construction of a NIMPLY logic gate with a H-AuNS probe was investigated to improve the specificity of $\mathrm{Hg}$ (II) detection. This unique logic gate used $\mathrm{Hg}$ (II) and $\mathrm{Pt}(\mathrm{IV})$ ions as input and the formation of small AuNPs as the output, as shown in Figure 10. A high output of signal coming from a high relative change in the SPR ratio or from a distinctive visual color change to red was assigned as the "ON" signal and output value of 1 . This two-input NIMPLY logic gate produced a high output (output $=1$ ) in the presence of a $\mathrm{Hg}(\mathrm{II})$ input alone (input for $\mathrm{Hg}(\mathrm{II})=1$, input for $\mathrm{Pt}(\mathrm{IV})=0)$. But when only $\mathrm{Pt}(\mathrm{IV})$ was present $(0,1)$ and both $\mathrm{Pt}(\mathrm{IV})$ and $\mathrm{Hg}(\mathrm{II})$ inputs $(1,1)$ were present, the formation of small AuNPs was suppressed (output $=0$ ) due to the preferential formation of $\mathrm{Au} / \mathrm{Pt}$ alloy on the H-AuNS surface [36,37]. The nanoparticles after the logic gate experiment were collected and further analyzed by ICP-MS. The ICP-MS results show that the AuNP possessed 4055 $\pm 120 \mathrm{Hg}$ atoms per AuNP and $3588 \pm 100 \mathrm{Pt}$ atoms per AuNP in the presence of $\mathrm{Hg}$ (II) and $\mathrm{Pt}(\mathrm{IV})$, respectively. But the number of $\mathrm{Hg}$ atoms were reduced dramatically when the $\mathrm{H}$-AuNS probe was exposed to the mixture of $\mathrm{Hg}$ (II) and $\mathrm{Pt}(\mathrm{IV})$ with $388 \pm 108 \mathrm{Hg}$ atoms and $3248 \pm 32 \mathrm{Pt}$ atoms per AuNP. This study reveals that $\mathrm{Pt}(\mathrm{IV})$ forms an alloy with $\mathrm{Au}$, which protects $\mathrm{H}$-AuNSs and inhibits the formation of small AuNPs. When both Pt(IV) and $\mathrm{Hg}(\mathrm{II})$ are present (input $=1,1$ ) in the water sample, a stronger interaction between $\mathrm{Pt}(\mathrm{IV})$ and $\mathrm{H}$-AuNSs $\left(\mathrm{E}_{\mathrm{Pt}(\mathrm{IV}) / \mathrm{Pt}}^{0}: 1.48 \mathrm{~V}\right)$ compared to $\mathrm{Hg}$ (II) and $\mathrm{H}-\mathrm{AuNSs}\left(\mathrm{E}^{0} \mathrm{Hg}(\mathrm{II}) / \mathrm{Hg}: 0.85 \mathrm{~V}\right)$ takes place, significantly lowering the effect of $\mathrm{Hg}$ in dissolving branches of H-AuNSs and strongly hindering the formation of small-sized AuNPs(output $=0$ ). 
(a)

\begin{tabular}{|c|c|c|}
\hline Input $\mathrm{Hg}(\mathrm{II})$ & Input Pt(IV) & Output \\
\hline 0 & 0 & 0 (off) \\
\hline 1 & 0 & 1 (on) \\
\hline 0 & 1 & 0 (off) \\
\hline 1 & 1 & 0 (off) \\
\hline
\end{tabular}$\quad \begin{gathered}\mathbf{H g}(\mathrm{II})- \\
\mathbf{H - A u N P s} / \mathbf{A u}(\mathrm{III}) / \mathbf{H C l} / \mathbf{H}_{2} \mathbf{O}_{2}\end{gathered}$

(b)

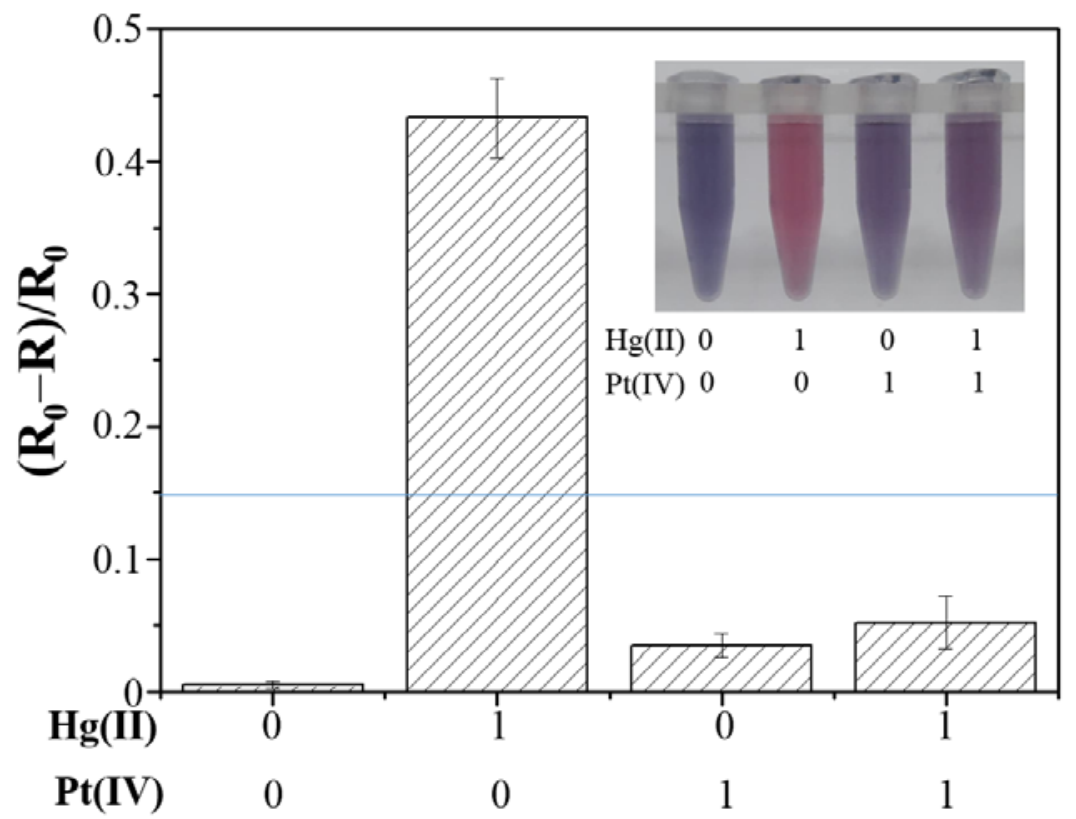

Figure 10. NIMPLY logic gate constructed using $\mathrm{Hg}(\mathrm{II}) / \mathrm{Pt}(\mathrm{IV})$ ions and the $\mathrm{H}-\mathrm{AuNS}$ probe in the presence of $\mathrm{HCl} / \mathrm{Au}(\mathrm{III}) / \mathrm{H}_{2} \mathrm{O}_{2}$ solution. (a) Schematic representation of the NIMPLY logic gate "Hg(II)/Pt(IV)(NIMPLY)-HAuNP"; (b) Bar diagram of output signals (formation of small AuNPs) in response to four different combinations of two inputs, $\operatorname{Hg}(\mathrm{II})(0,10 \mu \mathrm{M})$ and $\mathrm{Pt}(\mathrm{IV})(0,10 \mu \mathrm{M})$. The threshold line is set to the 0.3-fold signal output of true (on). Error bars represent standard deviations from three repeated experiments. Other conditions were the same as those described in Figure 1.

\section{Conclusions}

In summary, a label-free nanosensor (H-AuNSs) was developed for colorimetric detection of $\mathrm{Hg}$ (II). Based on dissolution of AuNSs in the presence of $\mathrm{Hg}$ (II) and formation of amalgam, the formation of AuNPs from $\mathrm{HCl} / \mathrm{Au}(\mathrm{III}) / \mathrm{H}_{2} \mathrm{O}_{2}$ was hindered by the reduced effective surface area and elemental composition. In other words, the $\mathrm{Hg}$ (II) regulates the AuNP formation on the surface of H-AuNS and affects the shape and size of the resulting AuNPs significantly enough to cause a visible color change as low as $10 \mathrm{nM}$ of $\mathrm{Hg}$ (II). Under the optimized conditions, the probe is selective to $\mathrm{Hg}$ (II) compared with other metal ions, producing a significant difference in the change of the SPR ratio, even at a low concentration of $\mathrm{Hg}(\mathrm{II})(1.0 \mu \mathrm{M})$. The linear detection range and $\mathrm{LOD}$ for $\mathrm{Hg}(\mathrm{II})$ in laboratory standards were $1.0 \mathrm{nM}-100 \mu \mathrm{M}$ and $0.7 \mathrm{nM}$, respectively. The good selectivity and sensitivity of this $\mathrm{H}$-AuNSs probe offer portable detection of $\mathrm{Hg}(\mathrm{II})$ in environmental water matrices to enhance crucial environmental conservation efforts. Furthermore, the competitive interaction between $\mathrm{Hg}$ (II) and $\mathrm{Pt}(\mathrm{IV})$ toward the H-AuNSs probe enables the development of a NIMPLY logic gate through the regulation of the nanocatalytic reaction of the H-AuNSs probe, increasing the specificity of this H-AuNS-based $\mathrm{Hg}$ (II) assay. 
Author Contributions: Conceptualization, Y.-W.L.; Data curation, P.-C.Y.; Formal analysis, P.-C.Y. and T.W.; Funding acquisition, Y.-W.L.; Investigation, P.-C.Y.; Methodology, P.-C.Y. and Y.-W.L.; Project administration, Y.-W.L.; Writing—original draft, Y.-W.L.; Writing—review \& editing, T.W. and Y.-W.L.

Funding: This research was funded by the Ministry of Science and Technology grant number (MOST 107-2113-M-018-005).

Conflicts of Interest: The authors declare no conflicts of interest.

\section{References}

1. Beckers, F.; Rinklebe, J. Cycling of mercury in the environment: Sources, fate, and human health implications: A. review. Crit. Rev. Environ. Sci. Technol. 2017, 47, 693-794. [CrossRef]

2. Ha, E.; Basu, N.; Bose-O’Reilly, S.; Dorea, J.G.; McSorley, E.; Sakamoto, M.; Chan, H.M. Current progress on understanding the impact of mercury on human health. Environ. Res. 2017, 152, 419-433. [CrossRef] [PubMed]

3. Lentini, P.; Zanoli, L.; Granata, A.; Santo Signorelli, S.; Castellino, P.; Dell'Aquila, R. Kidney and heavy metals-The role of environmental exposure. Mol. Med. Rep. 2017, 15, 3413-3419. [CrossRef] [PubMed]

4. Maqbool, F.; Niaz, K.; Hassan, F.I.; Khan, F.; Abdollahi, M. Immunotoxicity of mercury: Pathological and toxicological effects. J. Environ. Sci. Health Part C Environ. Carcinog. Ecotoxicol. Rev. 2017, 35, $29-46$. [CrossRef] [PubMed]

5. Suherman, A.L.; Tanner, E.E.L.; Compton, R.G. Recent developments in inorganic $\mathrm{Hg}^{2+}$ detection by voltammetry. TrAC Trends Anal. Chem. 2017, 94, 161-172. [CrossRef]

6. Suvarapu, L.N.; Baek, S.O. Recent studies on the speciation and determination of mercury in different environmental matrices using various analytical techniques. Int. J. Anal. Chem. 2017, 2017, 3624015. [CrossRef] [PubMed]

7. Yan, F.Y.; Fan, K.Q.; Bai, Z.J.; Zhang, R.Q.; Zu, F.L.; Xu, J.X.; Li, X. Fluorescein applications as fluorescent probes for the detection of analytes. TrAC Trends Anal. Chem. 2017, 97, 15-35. [CrossRef]

8. Lin, Y.W.; Huang, C.C.; Chang, H.T. Gold nanoparticle probes for the detection of mercury, lead and copper ions. Analyst 2011, 136, 863-871. [CrossRef] [PubMed]

9. Lin, Y.W.; Liu, C.W.; Chang, H.T. DNA functionalized gold nanoparticles for bioanalysis. Anal. Methods 2009, 1, 14-24. [CrossRef]

10. Priyadarshini, E.; Pradhan, N. Gold nanoparticles as efficient sensors in colorimetric detection of toxic metal ions: A review. Sens. Actuator B Chem. 2017, 238, 888-902. [CrossRef]

11. Ullah, N.; Mansha, M.; Khan, I.; Qurashi, A. Nanomaterial-based optical chemical sensors for the detection of heavy metals in water: Recent advances and challenges. TrAC Trends Anal. Chem. 2018, 100, 155-166. [CrossRef]

12. Walekar, L.; Dutta, T.; Kumar, P.; Ok, Y.S.; Pawar, S.; Deep, A.; Kim, K.H. Functionalized fluorescent nanomaterials for sensing pollutants in the environment: A. critical review. TrAC Trends Anal. Chem. 2017, 97, 458-467. [CrossRef]

13. Xu, F.J.; Hu, J.; Zhang, J.Y.; Hou, X.D.; Jiang, X.M. Nanomaterials in speciation analysis of mercury, arsenic, selenium, and chromium by analytical atomic/molecular spectrometry. Appl. Spectrosc. Rev. 2018, 53, 333-348. [CrossRef]

14. Zarlaida, F.; Adlim, M. Gold and silver nanoparticles and indicator dyes as active agents in colorimetric spot and strip tests for mercury(II) ions: A review. Microchim. Acta 2017, 184, 45-58. [CrossRef]

15. Huang, C.C.; Chang, H.T. Parameters for selective colorimetric sensing of mercury(II) in aqueous solutions using mercaptopropionic acid-modified gold nanoparticles. Chem. Commun. 2007, 12, 1215-1217. [CrossRef] [PubMed]

16. Chen, J.L.; Yang, P.C.; Wu, T.; Lin, Y.W. Determination of mercury (II) ions based on silver-nanoparticles-assisted growth of gold nanostructures: UV-vis and surface enhanced Raman scattering approaches. Spectrochim. Acta Part A Mol. Biomol. Spectrosc. 2018, 199, 301-307. [CrossRef] [PubMed]

17. Habib, A.; Tabata, M.; Wu, Y.G. Formation of gold nanoparticles by good's buffers. Bull. Chem. Soc. Jpn. 2005, 78, 262-269. [CrossRef]

18. Xie, J.P.; Lee, J.Y.; Wang, D.I.C. Seedless, surfactantless, high-yield synthesis of branched gold nanocrystals in hepes buffer solution. Chem. Mater. 2007, 19, 2823-2830. [CrossRef] 
19. Jena, B.K.; Raj, C.R. Synthesis of flower-like gold nanoparticles and their electrocatalytic activity towards the oxidation of methanol and the reduction of oxygen. Langmuir 2007, 23, 4064-4070. [CrossRef] [PubMed]

20. Xie, J.P.; Zhang, Q.B.; Lee, J.Y.; Wang, D.I.C. The synthesis of SERS-active gold nanoflower tags for in vivo applications. ACS Nano 2008, 2, 2473-2480. [CrossRef] [PubMed]

21. Jena, B.K.; Raj, C.R. Seedless, surfactantless room temperature synthesis of single crystalline fluorescent gold nanoflowers with pronounced sers and electrocatalytic activity. Chem. Mater. 2008, 20, 3546-3548. [CrossRef]

22. Chen, R.; Wu, J.L.; Li, H.; Cheng, G.; Lu, Z.; Che, C.M. Fabrication of gold nanoparticles with different morphologies in HEPES buffer. Rare Met. 2010, 29, 180-186. [CrossRef]

23. Maiorano, G.; Rizzello, L.; Malvindi, M.A.; Shankar, S.S.; Martiradonna, L.; Falqui, A.; Cingolani, R.; Pompa, P.P. Monodispersed and size-controlled multibranched gold nanoparticles with nanoscale tuning of surface morphology. Nanoscale 2011, 3, 2227-2232. [CrossRef] [PubMed]

24. Chen, S.H.; Wang, Z.L.; Ballato, J.; Foulger, S.H.; Carroll, D.L. Monopod, bipod, tripod, and tetrapod gold nanocrystals. J. Am. Chem. Soc. 2003, 125, 16186-16187. [CrossRef] [PubMed]

25. Kuo, C.H.; Huang, M.H. Synthesis of branched gold nanocrystals by a seeding growth approach. Langmuir 2005, 21, 2012-2016. [CrossRef] [PubMed]

26. Wu, H.Y.; Liu, M.; Huang, M.H. Direct synthesis of branched gold nanocrystals and their transformation into spherical nanoparticles. J. Phys. Chem. B 2006, 110, 19291-19294. [CrossRef] [PubMed]

27. Hao, E.; Bailey, R.C.; Schatz, G.C.; Hupp, J.T.; Li, S.Y. Synthesis and optical properties of "branched" gold nanocrystals. Nano Lett. 2004, 4, 327-330. [CrossRef]

28. Yamamoto, M.; Kashiwagi, Y.; Sakata, T.; Mori, H.; Nakamoto, M. Synthesis and morphology of star-shaped gold nanoplates protected by poly(n-vinyl-2-pyrrolidone). Chem. Mater. 2005, 17, 5391-5393. [CrossRef]

29. Bakr, O.M.; Wunsch, B.H.; Stellacci, F. High-yield synthesis of multi-branched urchin-like gold nanoparticles. Chem. Mater. 2006, 18, 3297-3301. [CrossRef]

30. Nehl, C.L.; Liao, H.W.; Hafner, J.H. Optical properties of star-shaped gold nanoparticles. Nano Lett. 2006, 6, 683-688. [CrossRef] [PubMed]

31. Wong, A.; Wang, H.J.; Poh, C.L.; Kitney, R.I. Layering genetic circuits to build a single cell, bacterial half adder. BMC Biol. 2015, 13, 40. [CrossRef] [PubMed]

32. Dam, D.H.M.; Culver, K.S.B.; Kandela, I.; Lee, R.C.; Chandra, K.; Lee, H.; Mantis, C.; Ugolkov, A.; Mazar, A.P.; Odom, T.W. Biodistribution and in vivo toxicity of aptamer-loaded gold nanostars. Nanomed. Nanotechnol. Biol. Med. 2015, 11, 671-679. [CrossRef] [PubMed]

33. Ouyang, H.X.; Li, C.N.; Liu, Q.Y.; Wen, G.Q.; Liang, A.H.; Jiang, Z.L. Resonance rayleigh scattering and sers spectral detection of trace $\mathrm{Hg}$ (II) based on the gold nanocatalysis. Nanomaterials 2017, 7, 114. [CrossRef] [PubMed]

34. Esdaile, L.J.; Chalker, J.M. The mercury problem in artisanal and small-scale gold mining. Chem. Eur. J. 2018, 24, 6905-6916. [CrossRef] [PubMed]

35. Zolnikov, T.R.; Ortiz, D.R. A systematic review on the management and treatment of mercury in artisanal gold mining. Sci. Total Environ. 2018, 633, 816-824. [CrossRef] [PubMed]

36. Lien, C.W.; Chen, Y.C.; Chang, H.T.; Huang, C.C. Logical regulation of the enzyme-like activity of gold nanoparticles by using heavy metal ions. Nanoscale 2013, 5, 8227-8234. [CrossRef] [PubMed]

37. Lien, C.W.; Tseng, Y.T.; Huang, C.C.; Chang, H.T. Logic control of enzyme-like gold nanoparticles for selective detection of lead and mercury ions. Anal. Chem. 2014, 86, 2065-2072. [CrossRef] [PubMed]

(C) 2018 by the authors. Licensee MDPI, Basel, Switzerland. This article is an open access article distributed under the terms and conditions of the Creative Commons Attribution (CC BY) license (http://creativecommons.org/licenses/by/4.0/). 